Winter 2016

\title{
The Temporal Rivalries of Human Rights
}

Fleur E. Johns

fleur.johns@unsw.edu.au, fleur.johns@unsw.edu.au

Follow this and additional works at: https://www.repository.law.indiana.edu/ijgls

Part of the Human Rights Law Commons, International Law Commons, and the Public Law and Legal Theory Commons

\section{Recommended Citation}

Johns, Fleur E. (2016) "The Temporal Rivalries of Human Rights," Indiana Journal of Global Legal Studies: Vol. 23 : Iss. 1 , Article 3.

Available at: https://www.repository.law.indiana.edu/ijgls/vol23/iss1/3

This Article is brought to you for free and open access by the Law School Journals at Digital Repository @ Maurer Law. It has been accepted for inclusion in Indiana Journal of Global Legal Studies by an authorized editor of Digital Repository@Maurer Law. For more information, please contactrvaughan@indiana.edu.

\section{$\Psi$}

JEROME HALL LAW LIBRARY

INDIANA UNIVERSITY

Maurer School of Law
Bloomington 


\title{
The Temporal Rivalries of Human Rights
}

\author{
FLEUR JOHNS*
}

\begin{abstract}
Nation-states' "boundaries" are produced in time: around official working hours and terms of office, for instance, and in the historicomythic "life of the nation." Global human rights practices affirm and depend on nation-states' temporal authority, while also calling that authority into question. In different ways, global markets do likewise. In recent decades, the ubiquity of both finance capital and international human rights law, among other factors, may have encouraged the fracturing of time into intervals of ever-decreasing length. Temporal authority premised on the long-term seems to have declining purchase, even as historicism and futurism abound, discouraging some modes of state-based politics associated with the long-term. In this context, international human rights law advocates seem increasingly preoccupied with the propagation of human rights concerns in "real time." This orientation carries some peril, especially vis-à-vis its articulation with the temporalities of global finance capital. Even so, there is still time for political intervention in this uneven temporal terrain. Such intervention may be occasioned, this article argues, by reading international human rights law anachronistically, and reactivating the times and rhythms of the global economy, and of the nation-state, as political questions of the first order.
\end{abstract}

* Professor of Law, UNSW Australia. I am indebted to Daniel Augenstein and Hans Lindahl for the invitation to develop a paper for the colloquium, "Global Human Rights Law and the Boundaries of Statehood," held at the Stellenbosch Institute of Advanced Study in March 2015 at which a prior version of this article was presented, both for that invitation and for generous and insightful editorial feedback. I am grateful also to the participants in that colloquium for their questions and suggestions, as I am to the organizers and audience members of the UNSW Law Staff Seminar and the University of Melbourne Legal Theory Forum at which prior versions of this paper were presented. Particular thanks are due to Cait Storr for her input as commentator and respondent at the latter event, to Ben Golder, Lucas Lixinski, John Morss, and Rosalind Dixon for comments, and to the editorial staff of the Indiana Journal of Global Legal Studies.

Indiana Journal of Global Legal Studies Vol. 23 \#1 (Winter 2016)

(C) Indiana University Maurer School of Law 


\section{INTRODUCTION}

"While the council remains an imperfect body, we have seen distinct progress in terms of its ability to respond to happenings in the world [with respect to human rights] in real time," [the U.S. ambassador to the UN Human Rights Council, Eileen Donahoe told reporters.] "There is more shared common ground here than people realize."

The "common ground" to which international human rights law lays claim today is, at least in part, temporally comprised. That which bearers and guardians of rights try to hold together is less any single measure of value than a sense of unavoidable coincidence in more or less the same time frame (an effort that often fails, as discussed below). That this coincidental time frame may be striated zonally, squared against disparate pasts and futures, and punctuated by events evoking variable degrees and durations of concern, need not alter its scaffolding cogency in and for international human rights law, if only it could be sustained. Much has been made, for instance, of prospects for global human rights to unfold "in real time"-that is, amid the sense of informational concurrence to which rapid data processing, crowdsourced reporting, and remote-sensing capacities afford ever more ready access. $^{2}$

Technological capacities notwithstanding, co-occurrence in time at any scale may arguably have become harder to sustain in recent decades, especially on the temporal terrain of statehood. Scholarly literature has recorded a "declining temporal authority of states" before the rhythms of global finance capital. ${ }^{3}$ In light of such claims, this article asks the following questions: to what extent, if at all, does international human rights law install or assert rival temporalities to those commonly associated with, and mobilized for and through, the nation-state? How might any such rival temporalities relate to the times

1. Editorial, The United Nations' Human 'Rights' Council, Wash. PosT, Mar. 27, 2011, at $\mathrm{A} 18$, available at http://www.washingtonpost.com/opinions/the-united-nationshuman-rights-council/2011/03/25/AFSRyPeB_story.html.

2. See, e.g., Joanna Naples-Mitchell, Perspectives of UN Special Rapporteurs on Their Role: Inherent Tensions and Unique Contributions to Human Rights, 15 INT'L J. HUM. RTS. 232, 232-33, 244 (2011). See generally Real Time Definition, OED ONLINE, http://www.oed.com/viewdictionaryentry/Entry/238662 (last visited Dec. 2014) ("The actual time during which a process or event occurs, esp. one analysed by a computer, in contrast to time subsequent to it when processing may be done, a recording replayed, etc.").

3. Wayne Hope, Conflicting Temporalities: State, Nation, Economy and Democracy Under Global Capitalism, 18 TLME \& SOC'Y 62, 78 (2009). 
and timings of global finance capital? What, moreover, may be some ramifications of such rivalries for those engaged in international legal work?

Part I of this article reviews temporal dimensions of international law writ broadly, including international human rights law. It considers some of the functions of time and timing in and for international law and the different forms that international legal temporality may take. In Part II, comparison is made to time and timings characteristic of the nation-state and the practice of assembling and maintaining nationstate authority temporally. In relation to both of these temporal styles or endeavors, this article then, in Part III, reflects on the declining credibility of the long-term over the course of the twentieth century, observing that there may have been, in many respects, contraction in the temporal intervals of public concern and experience. ${ }^{4}$

Against this background, as I argue in Part IV, international human rights law is advanced as a somewhat untimely discipline, not subscribing consistently either to the temporal templates of the nationstate, or to the accelerated rhythms and shortened spans of the global market. Instead, international human rights law doctrine and practice - exemplified here by the International Covenant on Civil and Political Rights (ICCPR) - seem to foster temporal fitfulness. ${ }^{5}$ At times, international human rights law work links, sequences, and periodizes; elsewhere it seeks to arrest a temporal flow. Paradoxically, this fitful temporality of international human rights law may be less about confirming rightful time-a temporality that is "on the right path"than about insistently evoking the "disjuncture of the unjust" through repeated alignments with, and disarticulations from, other temporal registers. ${ }^{6}$

For purposes of this argument, temporalities characteristic of the nation-state, global finance capital or the global market, and international human rights law, respectively, are sketched quite schematically and posited as rivals, even as complicity and reliance

4. This is not a claim that may be verified or proven on the basis of material presented in this article. Rather, this article relies, in Part III, upon scholarship drawn from a range of fields that is suggestive of this prospect. Moreover, it is not essential to the argument of this article that concern for the long-term be in decline as a general matter, for all times and for all peoples everywhere. Examples of countering tendencies are doubtless readily available.

5. International Covenant on Civil and Political Rights, G.A. Res. 2200A (XXI), U.N. Doc. A/6316 (Dec. 16, 1966) [hereinafter ICCPR] (detailing a series of agreed-upon human rights propositions, focused primarily on freedom and equality).

6. JACQUes DerRida, Specters of MARX: THE State of the DebT, THE WORK of Mourning, AND THE NeW InTERnational 20-22 (Peggy Kamuf trans., Routledge 1994) (1993). 
among them are made apparent. In so doing, this article's aims are twofold. On one hand, this triptychal redescription is intended to sharpen the visibility of relations between these phenomena, and thereby to counter any sense that the discipline of international human rights law militates, necessarily, against the nation-state or the market. ${ }^{7}$ On the other hand, their stylized separation is designed to recover some prospect that international human rights law might, nonetheless, retain rivalrous potential - that is, that it might still provoke the disjuncture of the unjust alluded to above.

In Part $\mathrm{V}$, finally, this article will explore how international human rights law as a discipline remains, nonetheless, preoccupied with trying to engender regular temporal rhythms more or less of its own production. In past decades, this has been bound up with the professionalization and global propagation of the human rights enterprise. More recently, however, effort has been directed towards that enterprise's decentralization and reseeding, including through the cultivation of itinerant temporalities capable of lodging within and moving with a crowd. It is with a critique of this aspiration-for human rights capable of gathering in "real time"-that this article will close, amid speculation as to what this might demand of those who would engage in international human rights law work and those whose rights they would defend.

\section{TEMPORALITIES OF INTERNATIONAL LAW}

Time is often cast-alongside space-as international law's background, or as the medium in which international legal relations and conduct are "set." 8 This casting is related to the propensity, since the nineteenth century, to set law in context amid the social. 9 "Society . .

7. For evidence of a still-subsisting tendency to characterize international human rights law as opposed to the imperatives of the nation-state and the global market, see, e.g., Louis Henkin, Human Rights and State "Sovereignty", 25 GA. J. INT'L \& CoMP. L. 31 (1995); Frank J. García, The Global Market and Human Rights: Trading Away the Human Rights Principle, 25 BROOK. J. INT'L L. 51, 53 (1999).

8. Keebet von Benda-Beckmann, Trust and the Temporalities of Law, 46 J. LEGAL PluRALISM \& UNOFFICIAL L. 1, 2 (2014).

9. Cf. Duncan Kennedy, Three Globalizations of Law and Legal Thought: 1850-2000, in The New LAW AND Economic Development: A CRITICAL APPRAisal 19, 19-22 (David M. Trubek \& Alvaro Santos eds., 2006) (describing the formalistic, classical legal thought of the late nineteenth century and early twentieth century and the socially oriented legal thought of the twentieth century, and how these two schools gave way to modern legal thought). See generally BRUNo LATOUR, REASSEMBLING THE SOCIAL: AN INTRODUCTION TO ACTOR-NETWORK-THEORY (2005) (making a sustained critique of the enterprise of "social explanation," including by reference to "context"). 
. [effects] a conceptual union of time and place"; in many scholars' accounts, law inhabits this unity as a phenomenon in and of the social. ${ }^{10}$ As Carol Greenhouse has shown, the temporalities of law's social settings - and hence law's own temporalities-have often been thought by recourse to Emile Durkheim's notion of collective, symbolic "social time."11 Yet timing is also a technique of international law: international law is a shaper of time and a connector and divider of times. International law sequences time and distributes humans and nonhumans within those sequences, according to narratives of progress, modernity, and development. ${ }^{12}$ International law maps time onto the surface of the Earth: Greenwich Mean Time and the international dateline are products of international treaty making and the work of international organizations. ${ }^{13}$ International law gathers people into the urgent temporality of crisis; indeed, some are lawfully consigned to conditions of "permanent crisis." ${ }^{14}$ It also fences people in deadlines, and channels work in a far more mundane register: by establishing continuous cycles of reporting and review under international human rights treaties, for instance. ${ }^{15}$

International legal temporalities are often linear and oriented around a point in time: the definite duration or the time-limited procedure; that is, the time of calendar and clock. Consider the dating and timing of treaties' entry into force, for example, or the insistence that International Court of Justice decisions bind only those who come

10. Carol J. Greenhouse, Just in Time: Temporality and the Cultural Legitimation of Law, 98 YALE L.J. 1631, 1638 (1989).

11. Carol J. Greenhouse, Time's Up, Timed Out: Reflections on Social Time and Legal Pluralism, 46 J. Legal PluRalism \& Unofficial L. 141, 141 (2014) (quoting EMILE Durkheim, The ElementaRy Forms of Religious Life (Karen Fields trans., Free Press 1995) (1912)).

12. See generally Thomas Skouteris, THE Notion of Progress in InTERnat'ionaL LAW DISCOURSE (2010) (discussing and challenging what is labeled as progress in the international law context).

13. See, e.g., Francis Deák, Computation of Time in International Law, 20 AM J. INT'L L. 502, 515 (1926); George Grafton Wilson, Editorial Comment, Time and International Law, 34 AM J. INT'L L. 496, 497 (1940).

14. Massimiliano Tomba, Clash of Temporalities: Capital, Democracy, and Squares, 113 S. ATLANTIC Q. 353, 354 (2014); see Hilary Charlesworth, International Law: $A$ Discipline of Crisis, 65 MOD. L. REV. 377, 377 (2002) (discussing how international lawyers focus on crises).

15. The Universal Periodic Review mechanism of the United Nations Human Rights Council is one prominent example. See generally Edward McMahon \& Marta Ascherio, $A$ Step Ahead in Promoting Human Rights? The Universal Periodic Review of the UN Human Rights Council, 18 Global GovernanCE 231 (2012) (discussing the Universal Periodic Review, a UN system by which states can make recommendations to each other about human rights practices). 
before the court in a "particular case." 16 Consider, too, Bin Cheng's famous contraction of customary international lawmaking into instant custom. ${ }^{17}$

Even so, international law speaks in and to durations of unspecified length and nonlinear dimensions: in the jurisdictional notion of "continuing acts" (where the conduct in question commenced before the existence of the norm allegedly violated, but continued after it came into effect); ${ }^{18}$ in limitations periods, which bar claims due to the passage of time; and in the doctrine of intertemporal law, which requires "judicial fact[s]" to be "appreciated in the light of the law contemporary with [them]."19 International law also extricates itself recurrently from the movement of time; international human rights law especially: it asserts the timelessness of its concerns, all the while worrying incessantly about its want of timeliness and its need to "catch up." 20

The temporalities of international law are thus multiple and misaligned. Just as there is no "general history," so there is no general temporality of international lawfulness. ${ }^{21}$ Indeed, assertions of overarching, free-floating temporality remain troubling, insofar as they prompt divergences to be experienced in terms of objectively ascribed "backwardness" and "advancement," the harms of which are well documented. ${ }^{22}$ If advocates of international law nonetheless exhibit a

16. Statute of the International Court of Justice art. 59, June 26, 1945, 33 U.N.T.S. 993; see ANThony AUST, MODERn TrEaty LAW AND PRACTICE 168-71 (2d ed., 2007); see also Liaquat Ali Khan, Temporality of Law, 40 MCGEORGE L. REV. 55, 59-69 (2009) (breaking down temporality into points in time and duration, for legal purposes).

17. See Bin Cheng, Custom: The Future of General State Practice in a Divided World, in The Structure and Process of InTernational LaW: Essays IN Legal Philosophy Doctrine AND Theory 513, 536 (R. St. J. Macdonald \& Douglas M. Johnston eds., 1983) (describing the Barcelona Declaration as an example of the author's belief that international law is created instantly by changes in what states accept and subscribe to as the law).

18. Rosalyn Higgins, Time and the Law: International Perspectives on an Old Problem, 46 INT'L \& COMP. L.Q. 501, 506 (1997).

19. United States v. Netherlands, Hague Ct. Rep. 2d (Scott) 83, at 845 (Perm. Ct. Arb. 1928).

20. See, e.g., Christoph Bezemek et al., Topics in International Human Rights Protection, 7 VIENNA J. ON INT'L CONST. L. 127, 127 (2013) (describing freedom of communication as a "timeless, ... never outdated topic in human rights protection"); Colin B. Picker, A View from 40,000 Feet: International Law and the Invisible Hand of Technology, 23 Cardozo L. REV. 149, 184 (2001) ("Normally, delay is the rule in the formation of international law.").

21. JaCques Derrida, Positions 50 (Alan Bass trans., Continuum 2d English ed. 2004) (1972) (commenting on Althusser's critique of an Hegelian notion of history).

22. ANTONY ANGHIE, IMPERIALISM, SOVEREIGNTY AND THE MAKING OF INTERNATIONAL LAW 189 (2005); cf. Louis Althusser, The Object of Capital, in READING CAPITAL 71, 106 (Ben Brewster trans., New Left Books 1970) (1968) ("II]t is only in the specific unity of the 
common temporal disposition, this may be discerned in the aspiration to link up disparate times and timings-in the impulse to join things together and thereby enjoin unlawfulness. ${ }^{23}$

\section{STATE TIMES}

To a significant degree, these rivalrous international legal temporalities pivot around the politico-legal figure of the nation-state and the temporalities constituting and sustained by it. The "structure of feeling" instilled by and for the nation-state has a significant temporal dimension. ${ }^{24}$ The latter-the temporality of the national-has, in Saskia Sassen's estimation, "remained submerged, an unnamed condition . . . partly because it is our given condition, the assumed temporality of much social scientific practice" 25 and, I would add, much legal practice as well. Nation-state time is produced in social and legal knowledge practices, but often tends to be illegible to them. ${ }^{26}$

Among those submerged temporalities, the generation of "synchronic" experience-a sense of parallelism or simultaneity among those spread across great distances and divergent geographic and life conditions-has been essential to the nation-state's creation, prevalence and endurance. ${ }^{27}$ Time had to be made cohabitable among scattered strangers in order for the nation-state to attain the dominance that it did between 1500 and 1800, and for humans to experience themselves as nation-bound "populations" or aspirants to that status. ${ }^{28}$ It was only through "an accumulation of technological innovations in the fields of

complex structure of the whole that we can think the concept of these so-called backwardnesses, forwardnesses, survivals and unevennesses of development which coexist in the structure of the real historical present . . . ."). Note the "whole" here is a contingent social formation: a "structural unity" that "contain[s] what can be called levels or instances which are distinct and 'relatively autonomous' .. . [but nonetheless] articulated with one another." Althusser, supra, at 97.

23. Cf. DERRIDA, supra note 6, at 25 ("The thinking of the jointure is also a thinking of injunction.").

24. Ana María Alonso, The Politics of Space, Time and Substance: State Formation, Nationalism and Ethnicity, 23 ANN. REV. ANTHROPOLOGY 379, 386-90 (1994).

25. Saskia Sassen, Spatialities and Temporalities of the Global: Elements for a Theorization, 12 PUB. CuLTURE 215, 223 (2000).

26. Cf. Althusser, supra note 22, at 101 (discussing the "invisible time" of capitalist economic production, and how that time system is not apparent to those in the system creating it).

27. Benedict Anderson, Imagined Communities 188 (rev. ed., 1991) (1983).

28. On the emergence of the phenomenon of the "population," see MICHEL FouCAULT,

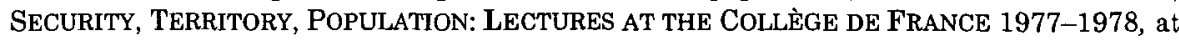
42-45, 66-79 (Michel Senellart et al. eds., Graham Burchell, trans., 2007) (2004). 
shipbuilding, navigation, horology and cartography, mediated through print-capitalism" that "this type of imagining [became] possible."29

Yet state time has significant diachronic dimensions as well. Many have shown the importance of the telling of history and myth to the ongoing project of nation-state making and remaking. ${ }^{30}$ Indeed, this is the way in which the temporality of nation-statehood has most commonly been thought. As Tim Edensor has observed, "accounts of the temporal constitution of national identities continue to focus upon common traditions, myths of shared descent, and the linking of historical and future narratives." 11 Both historico-mythic time and the presumed copresence of the nation-state in turn evoke and rely upon an "ideological base time": an undifferentiated emptiness or unity, through which people and things may pass, or in which they may be held for a time. ${ }^{32}$

However empty it may seem, this "base time" underpinning the authority of the nation-state is itself sequenced and sectioned according to temporalities of office, planning, and indebtedness: temporalities differentiated on their face. Such sequences include the term of service, the duration of appointment, or the maturity of sovereign bonds. In democratic states, time is parceled out according to the election cycle. In all political settings, year-on-year budget cycles tend to set the national rhythm. In most settings, furthermore, state time corresponds to budgetary and policy planning periods of longer duration, both domestic and international: five-year plans, for example, or the pre- and post2015 planning and measurement surrounding the Millennium Development Goals. ${ }^{33}$

National temporalities are comprised, too, of the everyday reproduced mundanely as "experience"-the everyday of public servants, for instance. This mode of temporality is most obviously synchronic, but generates a sense of base time as well. Conventionally, state time has been imagined as "slow moving" thanks to the "rule-

29. ANDERSON, supra note 27.

30. See, e.g., ANThoNy D. SMith, National IDENTITY 66 (Univ. of Nev. Press 1993) (1991).

31. Tim Edensor, Reconsidering National Temporalities: Institutional Times, Everyday Routines, Serial Spaces and Synchronicities, 9 EUR. J. SOC. THEORY 525, 527 (2006).

32. Althusser, supra note 22, at 104-05.

33. See, e.g., Peter T.Y. Cheung, China's Changing Regional Development: Trends, Strategies and Challenges in the 12th Five-Year Plan (2011-2015) Period, 53 ASLA PAC. VIEWPOINT 1, 1 (2012); Francis Collins \& David Galas, A New Five-Year Plan for the U.S. Human Genome Project, 262 SCIENCE 43, 46 (1993); Chris Ham, Another Five Year Plan for the NHS, 340 BRIT. MED. J. 5, 5-6 (2010); U.N. Economic and Social Council, Millennium Development Goals and Post-2015 Development Agenda, http://www.un.org/en/ecosoc/about/mdg.shtml (last visited June 12, 2015). 
bound public accountability of governmental processes." ${ }^{34}$ Yet this impression may have little or no grounding in the recent experience of government employees under pressure from incentive structures, efficiency demands, and austerity measures..$^{35}$ Increasingly, state time is the defined contract period of a consultant's assignment. Likewise, it may be inapt to characterize contemporary democracy as proceeding at the "leisurely pace" of "deliberation." 36 Rather, it seems just as fitting to temporalize democracy by reference to the 150 - to 250 -hertz refresh rate of an LCD screen.

Mundane temporalities comprising "base" experiences of nationhood are not, moreover, solely the preserve of those in governmental employ. The everyday of state time is composed just as much of broadcasting schedules, speed restrictions, opening and trading hours, and the cycle of national holidays: all established by national or subnational law. ${ }^{37}$ Through both official and unofficial routinization, "national synchronicity is achieved [among a populace] through temporal customs about when and where specific social practices should occur." 38 Yet temporalities of national habit also diverge: the public holiday may pass without notice for those on "flexible" work schedules and those engaged in subsistence production or other forms of unpaid work. ${ }^{39}$ The maintenance of state time may be less about the synchronization (or making diachronic) of time across any one national population than the attempt to smooth over irrepressible temporal disjuncture or to organize

34. Sassen, supra note 25 , at 224.

35. See generally Donald F. KetTl, The Transformation of Governance: Public ADMINISTRATION FOR TWENTY.FIRST CENTURY AMERICA (2002) (explaining that the study of public administration is out of sync with its actual practice); Stephen Bach, Shrinking the State or the Big Society? Public Service Employment Relations in an Era of Austerity, 43 INDUS. REL. J. 399 (2012) (considering the origins of Big Society and its consequences on public service and the workforce in the UK); Peter Leisink \& Stephen Bach, Economic Crisis and Municipal Public Service Employment: Comparing Developments in Seven EU Member States, 20 TRANSFER 327 (2014) (examining the impact of austerity policies on municipal employment).

36. Contra Sheldon Wolin, What Time Is It?, THEORY \& EVENT (1997), https://muse.jhu.edu/journals/theory_and_event/v001/1.1wolin.html.

37. See Edensor, supra note 31, at 530-31.

38. Id. at 534 .

39. See generally Nancy Folbre, The Care Economy in Africa: Subsistence Production and Unpaid Care, 23 J. AFR. ECON. (SUPPLEMENT 1) i128 (2014) (analyzing the care economy in Africa, including subsistence farming and caring for dependents); Janice Peterson \& Barbara Wiens-Tuers, Work Time, Gender, and Inequality: The Conundrums of Flexibility, 48 J. ECON. ISSUES 387 (2014) (discussing flexible work schedules in the United States, with a particular focus on the impact on women workers). 
such disjunctions in and around relatively stable spatio-temporal containers. ${ }^{40}$

\section{THE DEMISE OF THE LONG-TERM}

Among the conditions of possibility for these contemporary legal temporalities and their spatio-temporal organization is the declining credibility of long-term planning and prediction over the course of the twentieth century. This decline has political, epistemological, cultural, technological, and economic dimensions.

Politically and epistemologically, the figure of the long-term planner and the viability of his or her predictive foresight has come under attack from both the right and the left. Friedrich Hayek famously cast doubt on the capacity of any human to comprehend or direct the "catallaxy" or "spontaneous order of the market" over any length of time. ${ }^{41}$ Hayek was not, of course, averse to planning, provided that it was "good planning." That is, it needed to be "wise and foresighted" enough to focus on enhancing competition rather then prescribing distributive outcomes to be realized at an "appointed time," or insisting on common ideals or objects to be pursued by all "at the same time." ${ }^{42}$ In Hayek's account, unification in planned time signified a loss of liberty through circumscription of choice, as well as a disregard for the imperfection of knowledge. Hayek's purported adversary in economic thought, John Maynard Keynes, likewise cast the future as radically unknowable and highlighted the relativity of time measurement. ${ }^{43}$

On the left of social and political thought, temporality has been fractured and particularized. In Louis Althusser's account, for instance, "peculiar time[s] and histor[ies]" were rethought as the outcome of distinct modes of production. ${ }^{44}$ Althusser's paired critiques of

40. See Tomba, supra note 14 , at 355 (discussing the difficulties that the diverging temporalities of democratic processes and capital present to governments).

41. 2 F. A. HAYEK, The Market Order or Catallaxy, in LAW, LEGISLATION, AND LiBERTY $107,108-09,128-29$ (1976).

42. F. A. HAYEK, THE ROAD TO SERFDOM 36, 55, 104 (1944).

43. Cf. Mogens Ove Madsen, Keynes's Early Cognition of the Concept of Time, in KEYNES'S GENERAL THEORY FOR TODAY 98, 106-09 (Jesper Jespersen \& Mogens Ove Madsen eds., 2012) (discussing how Keynes developed a dynamic notion of time). Hayek and Keynes are described as purported adversaries because the relationship of neoliberal (including Hayekian) thought to Keynesian thought and policy cannot be characterized as one of straightforward opposition. Hayek's ally Milton Friedman emphasized, for example, "what a great economist Keynes was and how much more [Friedman] sympathize[d] with his approach and aims than those of many of [Keynes'] followers." Milton Friedman, Comments on the Critics, 80 J. PoL. ECON. 906, 908 (1972).

44. Althusser, supra note 22 , at 99 . 
empiricism and historicism demanded a notion of differential time that could neither be read off the surface of events, nor understood as the continuity in which events occurred. Rather, according to Samuel Chambers, Althusser construed temporality as "emanating from the structure of the social formation." 45

Communication and cultural practices have also reinforced a sense of long-term planning as declining in cogency and coherence. In the course of historicizing this decline (rather ironically), Frederic Jameson has observed: "it is scarcely fair to expect long-term projections . . from minds trained in the well-nigh synchronic habits of zero-sum calculation and of keeping an eye on profits," all while subscribing to "pattern[s] of immediacies" in daily life-calling people rather than making appointments, for instance.46 To Jameson, the "end of temporality" staged in art and literature after modernism, and an associated "reduction to the present and . . . to the body," express the unrealizable aspirations of late capitalism. ${ }^{47}$

However one casts the causal dice, "patterns of immediacies" have certainly flourished and spread under late capitalism. Accelerated processing capacities and remote-sensing and robotics technologies have been coproduced with a just-in-time preoccupation in manufacturing, distribution, labor, and servicing. As supply chains have dispersed globally, temporal sequencing and coordination have demanded far greater attention and effort than ever before. Logistics-the "banal and technocratic management of the movement of stuff'48_may have become "the central discipline of the contemporary world" in commercial as much as in military endeavors. ${ }^{49}$ With this has thrived a sense of time as among the elements of the "stuff" to be managed and moved, typically with a view to minimizing stoppages and friction. ${ }^{50}$ That "seamless" global supply chains often turn out to be "messy and violent" in operation need not dissipate the sense of time as an endless series of micro-instances to be smoothed, linked, and aligned. Indeed, awareness of messiness and violence may, in fact, intensify such preoccupations. ${ }^{51}$

As noted at the outset, global financial practices have also intensified this orientation towards intervals of ever-decreasing length.

45. Samuel A. Chambers, Untimely Politics avant la lettre: The Temporality of Social Formations, 20 TIME \& SoC'Y 197, 208 (2011).

46. Fredric Jameson, The End of Temporality, 29 CRITICAL INQUIRY 695, 705-07, (2003).

47. Id. at 717 .

48. Deborah Cowen, The Deadly life of Logistics 4 (2014).

49. Nigel Thrift, Non-Representational Theory: Space, Politics, Affect 95 (2008)

50. CowEN, supra note 48 , at 93.

51. Id. 
As Wayne Hope has described, "[t]he real time profit making of financialized capitalism preclude[s] reflection on the volatilities of economic history and the uncertainties of future economic developments" and creates conflict with "longer term rhythms of capital accumulation centred upon production, commodity exchange and aggregate demand."52 The increased popularity of mathematical methods in finance from the 1970s onwards, and the rise of automated trading, have also been associated with a contraction in time intervals measured or modeled to the point of the infinitesimal. Continuous-time methods, assuming that the value of particular variables is continuously changing, have increasingly been deployed in the valuation of derivatives and other financial instruments in asset pricing and portfolio optimization. ${ }^{53}$ More recently, the use of software algorithms to identify and execute transactions has come to dominate securities trading. ${ }^{54}$ In such contexts "[m]illiseconds matter" to the realization of arbitrage opportunities in pricing patterns only detectable by electronic means. ${ }^{55}$ For finance capital, temporality has become less a dimension to occupy than one to chase or flee.

\section{THE UNTIMELINESS OF INTERNATIONAL HUMAN RIGHTS LAW}

International human rights law doctrine and practice are, in many respects, temporally parasitic on the conditions and constructions outlined above. Acts of asserting or claiming human rights protected by international law are typically oriented towards one or more nationstates. As such, human rights claims often entail affirmation of some nationalist "rationalization of time," by evoking nationalist or

52. Wayne Hope, Crisis of Temporalities: Global Capitalism After the 2007-08 Financial Collapse, 20 TIME \& Soc'Y 94, 101, 106 (2011); see also Hope, supra note 3, at 67 (criticizing trends in global capitalism and finance as setting the stage for currency crises). This may be less the case in certain industries-in the energy and natural resources sector, for instance-although these sectors may not be immune to managerial "shorttermism." See generally Kevin J. Laverty, Managerial Myopia or Systemic Short-termism?: The Importance of Managerial Systems in Valuing the Long Term, 42 MGMT. DECISION 949 (2004) (examining organizational culture, processes, and routines to understand why firms undervalue the long term when trading off between short-term and long-term results).

53. See Suresh M. Sundaresan, Continuous-Time Methods in Finance: A Review and an Assessment, 55 J. FIN. 1569, 1569 (2000).

54. See Donncha Kavanagh et al., Finance Past, Finance Future: A Brief Exploration of the Evolution of Financial Practices, 9 MGMT. \& ORG. HIsT. 135, 142 (2014).

55. Id. at 142. See generally Donald MacKenzie, How to Make Money in Microseconds, LONDON REV. BoOKS, May 19, 2011, at 16 (discussing the use of algorithms in stock market trading, with a focus on how quickly they facilitate trades). 
protonationalist diachrony, for instance. ${ }^{56}$ One influential version of disciplinary self-understanding has cast international human rights law as the chastened European progeny of the Second World War and the Holocaust. ${ }^{57}$ Other versions confer on international human rights law a more ancient national or protonational lineage-traceable to the Stoics of Greek and Roman philosophy, medieval scholars of natural rights, and the French, the American, and sometimes the Russian Revolutions. ${ }^{58}$ Accounts along these lines may be in the process of being usurped, among human rights historians, by a post-1970s periodization focused on the United States. ${ }^{59}$

International human rights law scholars and practitioners are nonetheless at pains to adapt to the rhythms of global supply chains and the lead-times of logistics. Increasingly, effort is directed towards the insertion of tiny packets of human rights review along the length of a global supply or value chain. Potentially open-ended claim-making and negotiation must be condensed, accordingly, into relatively rapidfire certification or audit, as market movements are broken down into interlaced milliseconds. 60

International human rights law scholars and practitioners do, nevertheless, exhibit some ambivalence about the submerged or invisible temporalities of nation-state and capitalist economy, even as they frequently pace their work according to those rhythms. At times, as in the quote with which this article opened, human rights advocates set an event-focused empiricism against such "background" temporalities.

56. Alonso, supra note 24 , at 388 .

57. See, e.g., Michael Ignatieff, Human Rights as Politics and Idolatry 4-5 (2001).

58. See, e.g., Adam McBeth Et AL., The InTERnational Law of Human Rights 36-58 (2011) (discussing the older legal traditions that influenced the idea of human rights). On contending "precursors" advanced for human rights among scholars and practitioners, including those mentioned here, see SAMUEL MOYN, THE LAST UTOPIA: HUMAN RIGHTS IN HISTORY 11-43 (2010).

59. See MOYN, supra note 58, at 3-6 (noting how human rights came into popular consciousness in the 1970s); Yves Dezalay \& Bryant Garth, From the Cold War to Kosovo: The Rise and Renewal of the Field of International Human Rights, 2 ANN. REV. L. \& Soc. SCI. 231, 240-53 (2006) (discussing human rights with a primary focus on the United States in the 1970s and 1980s); see also SAMUEL MOYN, HUMAN RIGHTS AND THE USES OF HISTORY 86 (2014) ("[T]he lesson of the actual history of human rights is that they are not so much a timeless or ancient inheritance to preserve as a recent invention to remake-or even leave behind....").

60. See Sarianna M. Lundan \& Peter Muchlinski, Human Rights Due Diligence in Global Value Chains, in 7 Progress In InTERnational Business Research 184 (Rob Van Tulder et al. eds., 2012). See generally Peter Lund-Thomsen \& Adam Lindgreen, Corporate Social Responsibility in Global Value Chains: Where Are We Now and Where Are We Going?, 123 J. BUS. ETHICS 11 (2014) (discussing and critiquing protections for workers in global value chains). 
Foregrounding "happenings in the world," framed in human rights terms, is frequently a way of trying to cut across the white noise and base time of nation and market. 61

Within international human rights law doctrine, it is also possible to discern effort to install some "base time" other than the vacant passageways or indifferent cycles of national history or global economy remarked on above. The ICCPR is, for example, strangely untimely. ${ }^{62}$

At first, the ICCPR seems hooked to a definite point in time: its dates of adoption and entry into force. Otherwise, however, it works to generate a patently fictional sense of States Parties' co-occurrence in and around the "present Covenant": a temporality plainly out of step with experience and impervious to measurement. ${ }^{63}$ Obligations in the ICCPR are expressed in the present tense: each State Party "undertakes" various commitments, even as the date of that initial undertaking will have been spread across many years, even decades, as states ratify or accede to the instrument and declare themselves subject to the jurisdiction of the Human Rights Committee. 64

Within this "present" of the ICCPR, allowance is made for interruptions: in "time of public emergency," certain derogations are permitted.65 Requirements flowing from rights' recognition are also afforded different pacing. Some steps must be taken "immediately," "promptly," "at the time of arrest," or "without undue delay." Others "shall be" taken at an unspecified rate or with allowance for "adequate time."66 Still others follow very specific calendar timings, as in the requirement to submit reports "[w]ithin one year of the entry into force of the present Covenant for the States Parties concerned." 67 At some points in the ICCPR text, biological time seems to be exerting a powerful undertow, literally or metaphorically: some requirements are triggered by a child's birth, while others track the "life of the nation." 68 Much of the text, however, has little if anything to do with biological time.

These interlocking rhythms evade empiricism in precisely the way that the timing of economic production has been shown to do. Consider the following from Louis Althusser's portion of Reading Capital:

61. See generally Fleur Johns et al., Introduction to EVENTS: THE FORCE OF INTERNATIONAL LAW 1 (Fleur Johns et al. eds., 2011) (discussing how international law makes events of certain occurrences, and the ramifications of doing so).

62. ICCPR, supra note 5.

63. Id. at art. 1(3).

64. Id. at art. 2(1)-(3).

65. Id. at art. 4(1).

66. Id. at arts. 4(3), 9(2)-(3), 14(3)(a)-(c), 24(2).

67. Id. at art. $40(1)(\mathrm{a})$.

68. Id. at arts. 4(1), 24(2). 
In the capitalist mode of production, . . . the time of economic production has absolutely nothing to do with the obviousness of everyday practice's ideological time: of course, it is rooted in certain determinate sites, in biological time, but ... it is not at all identified with this biological time, and in no sense is it a time that can be read immediately in the flow of any given process. It is an invisible time... as invisible and as opaque as the reality of the total capitalist production process itself. This time, as a complex "intersection" of . . . different times, rhythms, turnovers, . . is only accessible in its concept, which, like every concept is never completely "given", [sic] never legible in visible reality: like every concept this concept must be produced, constructed. 69

It is, nonetheless, questionable whether the work of international human rights law since the late twentieth century has effectively produced some "invisible" time or times through which other timings might pass, across or against rival temporalities, in the manner of which Althusser writes. Temporally, international human rights law doctrine, such as that set forth in the ICCPR, is irreducible to the composite times of nation and market, even as it occasionally evokes one or both of those. Yet international human rights law doctrine seems too temporally obstreperous and erratic to have become taken for granted. Here, it works to smooth over temporal divergence in the name of some universal time or timelessness; there, it ramps up temporal disjunction. ${ }^{70}$

Regardless of the success of efforts to reconfigure base time, it may be that the contemporary prevalence of human rights claims and consciousness has contributed to the "patterns of immediacies"

69. Althusser, supra note 22 , at 101 . In drawing a parallel to Althusser's notion of base time, the intention here is not to posit a claim that the temporalities of international human rights law or of nation-states are uniformly determined by, or responsive to, the rhythms of the capitalist means of production. In this article, base time is employed to elucidate temporalities that elude empiricism yet nonetheless seem to exert a metronomic compulsion in relation to other times and timings-temporalities that may, in this article's account, be multiple and contending.

70. See, e.g., Neil J. Kritz, Coming to Terms with Atrocities: A Review of Accountability Mechanisms for Mass Violations of Human Rights, 59 LAW \& CONTEMP. PROBS. 127, 12728 (1996) ("Dealing with the grieving, with accountability and forgiveness, and with the rehabilitation of victims and perpetrators will . . take time-certainly longer than the time generally allotted for technical tasks"; yet, "[a] public airing and condemnation ... may be the best way to draw a line between past and present, lest the public perceive the new order as simply more of the same."). 
remarked on above. International human rights practice certainly encourages planning: the Millennium Development Goals project mentioned earlier is illustrative of this. ${ }^{71}$ Nonetheless, human rights claims do seem designed for continuous time (meted out in infinitesimal intervals), or the time of the instant, rather than for discrete time of prescribed duration. Such claims are meant to be both ever-present individual accompaniments and actionable, in relation to any instance of infraction, with relative promptness.

One possible understanding of the temporality of international human rights law doctrine and practice is that they install, or seek to install, a "timeless...presence." 72 That is, the attribution and bearing of human rights might be taken to express that temporality that Hannah Arendt regarded as characteristic of both modernity and totalitarianism, whereby time is seized by "a superior process of movement"73 of which individuals become "walking embodiments."74 In Arendt's account, this temporal logic subordinates all individuated tasks and intervals-including the interval of a human lifespan-to an "ever ongoing process of purge and elimination" towards some future condition forever in the making. ${ }^{75}$ Thus the preamble to the ICCPR places the individual, in the present, "under a responsibility to strive for the promotion and observance of the rights recognized in the present Covenant," in service of "the inherent dignity of the human person."76 Read together with Arendt, this inherent dignity presumed by the ICCPR seems to call forth a "deadly eternity" whereby individuals' dignity is the natural residue of, and material for, the necessary unfolding of the international human rights law project, rather than something to be realized variably and agentially. ${ }^{77}$

To read international human rights law's temporalities so, however, would be to elide the sense of temporal dislocation. that they repeatedly evoke. Into the compressed "time of public emergency," when the

71. U.N. Economic and Social Council, supra note 33.

72. 1 HANNAH ARENDT, Thinking, in THE LIFE OF THE MIND 1, 207 (Mary McCarthy ed., 1978). I am indebted to Daniel Augenstein and Hans Lindahl for prompting me to consider this prospect.

73. Kathrin Braun, Biopolitics and Temporality in Arendt and Foucault, 16 TIME \& SoC'Y 5, 12 (2007) (quoting an independently translated phrase from HANNAH ARENDT, ELEMENTE UND URSPRÜNGE TOTALER HERRSCHAFT: ANTISEMITISMUS, IMPERIALISMUS, TOTALE HERRSCAFT 952 (Piper Verlag 5th ed. 1996) (1955)).

74. HANNAH ARENDT, On the Nature of Totalitarianism: An Essay in Understanding, in ESSAYS IN UNDERSTANDING: 1930-1954, at 328, 340 (Jerome Kohn ed., Schocken Books 2005) (1994).

75. Braun, supra note 73 , at 13 .

76. ICCPR, supra note 5, Preamble.

77. Braun, supra note 73 , at 15 . 
"exigencies of the situation" otherwise fill the frame, the ICCPR inserts an atemporal "no" in the form of the "no derogation" language of Article 4(2). ${ }^{78}$ Amid the dreamy timelessness of "[a]ll persons shall be equal before the courts and tribunals," in Article 14, one is called to pay close attention to practicalities, including ensuring that a person facing criminal charges has "adequate time and facilities for the preparation of his [or her] defence."79 It is possible to press much of the ICCPR into the temporal service of nationhood, market, family, and narratives of historical progress. Yet it is also possible to read and perform international human rights law anachronistically and thereby to amplify its "radical untimeliness." 80

\section{The CaLl of THE CROWD}

If international human rights law doctrine and practice tend towards the temporally unruly-perhaps even radical anachrony-they nonetheless remain oriented towards representation and rallying. Indeed, crucial to all the temporalities discussed so far is the prospect of their being produced as a mode of experience. Even the elusive temporalities of economy and nation-state must be made accessible or recordable in some sense, however indirectly. This in turn demands that the time or timing in question have some constituency-some people loyal (consciously or otherwise) to that temporality's production and reproduction.

As to how that constituency might be assembled and held together temporally, some historical differentiation seems in order. In international human rights law work, the period from the 1970s through the 2000s was broadly preoccupied with human rights law's professionalization and global inculcation. One aspect of this work was temporal. It entailed encouraging an ever-broadening range of actors to engage in the regular, ritualized recitation of human rights norms:

78. ICCPR, supra note 5, at art. 4(1)-(2).

79. Id. at art. 14(1), (3)(b).

80. DERRIDA, supra note 6 , at 25 (writing of that "anachrony on the basis of which we are trying here to think the ghost" in the course of developing a reading of spectral dimensions of Karl Marx's work). This article is not concerned with the historiography of international human rights law, nor with that of international law more broadly. For this reason, it takes no explicit part in debates to which Anne Orford has contributed her own forceful defense of anachronism. See Anne Orford, The Past as Law or History? The Relevance of Imperialism for Modern International Law (NYU Institute for International Law and Justice, Working Paper No. 2012/2 (History and Theory of International Law Series), June 2012). See also Martti Koskenniemi, Histories of International Law: Significance and Problems for a Critical View, 27 TEMPLE INT'L \& COMP. LJ. 215, 226-32 (2013). 
through governmental and intergovernmental reporting (or nongovernmental shadow reporting) and state submission to periodic review, for instance, as well as through participation in seasonal cycles of conference attendance and multilateral meeting. ${ }^{81}$ It is by such means that more and more people have been encouraged to locate themselves amid a progressive temporality marked out in human rights terms-to envisage themselves moving away from rights-infringing pasts towards rights-respecting futures. ${ }^{82}$

As far as rivalry between such a rights-oriented time scale and temporalities of nationhood is concerned, this seems to have been intermittent. Much international human rights law work of this period tracked the rhythms of state-to-state diplomacy, or sought to rewrite national myth.83 At the same time, this work sought to instill the perception of rights bearing as an everyday popular occurrence: as routine for many as consumer choice (at least for those with the requisite economic means). Moreover, international human rights law work of these decades remained self-consciously ruptive: it was designed to stop the clock on any "business as usual" deemed to have violated rights. ${ }^{84}$

By 2010, however, it was possible to regard this work of professionalization and routinization as largely done, human rights having attained "ideological ascendancy," and international human rights law's heroes, defenders, and norms attracting, in many circles, "uncritical wonderment." 85 Henceforth, even as the above-mentioned

81. See, e.g., David Kennedy, Autumn Weekends: An Essay on Law and Everyday Life, in LAW AND EverYDAY LIFE 191, 191-96 (Austin Sarat \& Thomas R. Kearns eds., 1993) (discussing the author's trip to Lisbon for an international law conference focused on East Timor); Video Lecture by Hilary Charlesworth, Rituals and Ritualism in the International Human Rights System, LONDON SCH. ECON. \& POL. ScI. (Oct. 21, 2014), http://www.lse.ac.uk/newsAndMedia/videoAndAudio/channels/publicLecturesAndEvents/p layer.aspx?id=2660 (discussing the U.N.'s role in human rights and the ritualized dimensions of that work).

82. See Joseph R. Slaughter, Enabling Fictions and Novel Subjects: The Bildungsroman and International Human. Rights Law, 121 PMLA 1405, 1410 (2006) (discussing a type of coming-of-age novel genre called "Bildungsroman" and discussing how it, and modern international human rights, encourage a progressive perspective). See generally SKOUTERIS, supra note 12.

83. See, e.g., Katharine E. McGregor, Memory Studies and Human Rights in Indonesia, 37 ASIAN STUD. REV. 350, 357-59 (2013) (discussing how Indonesian human rights proponents reassessed late 1960 s violence against communists). But see George E. Edwards, Assessing the Effectiveness of Human Rights Non-Governmental Organizations (NGOs) from the Birth of the United Nations to the 21st Century: Ten Attributes of Highly Successful Human Rights NGOs, $18 \mathrm{MICH}$. ST. J. INT'L L. 165 (2010) (focusing on the importance of non-state actors in international human rights law).

84. See, e.g., Kritz, supra note 70, at 127-28.

85. MOYN, supra note 58 , at 6-7. 
rituals remained ongoing, attention would turn to producing new times in which human-rights awareness might occur and recur.

In this regard, it seems to have become harder, in recent decades, to treat time in any register as common terrain across which all people must pass and through which all must come to pass. The narratives of development and progress with which international human rights law doctrine has long been inflected do not seem to stabilize or explain to the extent that they might once have done. In what sense, for instance, might a young, unskilled, unemployed person in the United States, a subsistence rice farmer in Laos, and an asylum seeker eking out the days of a hunger strike in detention in Australia be understood to occupy the same time scale? Where should we place these figures on a progressive timeline ostensibly spanning the globe? Even if such placement were possible, the passage of time often seems otherwise contrary to the aims of human rights activists. ${ }^{86}$

In the face of such challenges, as well as the decline of some forms of nation-state temporal authority discussed above, international human rights law doctrine and practice seem to have become somewhat less oriented around whispering ad nauseam in the ear of political elites (in the mode encouraged by postwar policy science). ${ }^{87}$ Instead, emphasis seems to now rest upon rallying or following crowds in some here-andnow-in a courtroom or at a protest, for instance-and maximizing the amplitude of the instant. ${ }^{88}$ This is, it seems, to be an era for rights in real time, or at least in some carefully sliced sections of real time. Champions of international human rights law seem to oscillate between appealing for a time of ubiquitous witnessing and unedited loops, and calling for such time to be punctuated and segmented so that collective

86. See Bruce Robbins, Temporizing: Time and Politics in the Humanities and Human Rights, BOUNDARY 2, Spring 2005, at 191, 193 ("Time protects those who are already too well protected. And since the goal of human rights activists is to deny impunity, to bring to account, for them ... time has been an antagonist ....").

87. Cf. Myres S. McDougal et al., Human Rights and World Public Order: A Framework for Policy-Oriented Inquiry, 63 AM. J. INT'L L. 237, 258-64 (1969) (discussing human rights law of the time in the context of state-to-state relations and elites).

88. See Sam Gregory, Cameras Everywhere: Ubiquitous Video Documentation of Human Rights, New Forms of Video Advocacy, and Considerations of Safety, Security, Dignity and Consent, 2 J. HUM. RTS. PRAC. 191, 193-94 (2010); see also Philip E. Agre, Real-Time Politics: The Internet and the Political Process, 18 InFo. Soc'y 311, 317, 321-22 (2002) (discussing the amplification model of internet advocacy, and the idea that technology fosters spacing among people by providing them with individual outlets while also allowing them to remain connected). See generally Heather Ford, Crowd Wisdom, INDEX ON CENSORSHIP, Dec. 2012, at 33 (discussing an online software platform for citizens to report human rights abuses in Kenya); Samuel Greengard, Following the Crowd, CoMM. AMC, Feb. 2011, at 20 (discussing the potential of crowdsourcing, including as a tool for reporting on human rights abuses). 
attention may be apportioned, directed, and intensified. The former recalls "Andy Warhol's ideal of filming real events in real time - life isn't edited, why should its record be edited?"--an aspiration now realized in countless blogs, remote-sensing facilities, and video diaries. ${ }^{89}$ The latter seems to evoke the piecemeal concreteness, diagnostic suggestiveness, and asocial "time depth" of the sequenced genome. 90

Producing instances or streams of shareable time has always taken work, but that work seems in many respects more difficult and less definitive than ever. Global human rights law doctrine and practicespecifically, the expectation that anyone, at any time, should be able to reach for a juridical right more or less instantly fungible with others' rights-seems both to have contributed to that difficulty and adapted to accommodate it. At the expense of radical anachrony, international human rights law doctrine and practice seem increasingly fixated on maximizing accumulated "interface time"; that is, "the physical span of time that [a] reader interacts" with a human rights-related text. ${ }^{91}$

\section{CONCLUSION}

What, then, might the prevailing impulse to sustain and occupy "real time," as against its temporal rivals, reveal about international human rights law work and workers today? Perhaps such "real time" preoccupations might be regarded as symptomatic of undue orientation toward times of crisis and associated inattention to "injustices of everyday life," amid the desire for "immediate, intense relevance."92 Today, however, international human rights law seems too expansive and too settled in its occupation of the everyday for critique along these lines to have much purchase. With so much mundane report filing and official investigation underway worldwide, it is unclear how much of an "alternative" an "international [human rights] law of everyday life" might pose. ${ }^{93}$ Moreover, the "real time" that human rights would tap is more often a source of preventative data than it is necessarily laden with crisis. The "real time" with which recurrent contact is sought

89. Susan Sontag, Regarding the Torture of Others, N.Y. TIMEs MAG., May 23, 2004, at $24,27$.

90. Kaja Finkler, Family, Kinship, Memory and Temporality in the Age of the New Genetics, 61 Soc. SCI. \& MED. 1059, 1065-67 (2005).

91. Marjorie C. Luesebrink, The Moment in Hypertext: A Brief Lexicon of Time, in

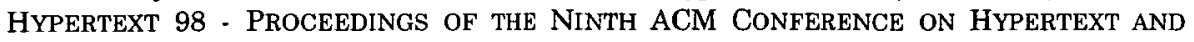
HYPERMEDIA 106, 107 (Frank Shipman et al. eds., 1998).

92. Charlesworth, supra note 14 , at 377,392 .

93. $I d$. at 377,391 . 
among international human rights law advocates is precisely the time of the everyday, avant la crise.

More troublingly, it may be that this orientation among international human rights law practitioners signals abandonment of much by way of a claim to power over the longue durée-the "cadres résistants"-of living and working conditions. ${ }^{94}$ Perhaps international human rights law doctrine and practice have, for the most part, now left the demarcation of invisible base time to the global economy, with its "real time" gatherings, protests, and live-streams being little more than diversions from, or elaborations on, the accelerating cadence of the market. It certainly appears, at times, as though global concern for capital (and temporal) redistribution might have dissipated in favor of concern for connectivity, liquidity, risk arbitrage, and continuous motion, the latter often explicitly rights-inflected.95 Perhaps, in the alternative, the real time aspirations of international human rights law work represent little more than a new iteration of the "given condition" of state time, with a renewed thrust for national synchronicity as their primary output. ${ }^{96}$ Consider, for example, how the much-vaunted, crowdsourced happenings of the Arab Spring gave way to divergent, yet similarly bleak, national winters. ${ }^{97}$

There is still time, though. If such abandonment or acquiescence has occurred, it is neither complete nor fully conceded. The base times of the nation-state and the global economy may be invisible, but the tolls that they sometimes exact do not go undetected. Everywhere one looks, the "proud, angry poor" are voicing and enacting dissatisfaction. ${ }^{98}$ If the ambition of this collection of writings is to "recover[ ] the public and

94. Fernand Braudel, Histoire et Sciences Sociales: La Longue Durée, 13 ANNALES. ÉCONOMIES, Sociétés, CIVILISATIONS 725, 733 (1958) (Fr.).

95. Since 2011, for example, the World Bank has published a Global Financial Inclusion (Global Findex) Database, funded by the Bill \& Melinda Gates Foundation, which measures how adults in 148 countries save, borrow, make payments and manage risk. Asli Demirguc-Kunt et al., The Global Findex Database 2014: Measuring Financial Inclusion Around the World, (World Bank Grp. Dev. Research Grp. Fin. and Private Sector Dev. Team, Policy Research Working Paper No. 7255, 2015), available at http://go.worldbank.org/1F2V9ZK8C0.

96. Sassen, supra note 25 , at 223.

97. See, e.g., David W. Lesch, The Arab Spring - and Winter - in Syria, 23 GLoBal CHANGe, PEACE \& SECURITY 421, $422-25$ (2011) (discussing Bashar al-Asad's crackdown on the opposition in Syria); Mary Ann Tétreault, The Winter of the Arab Spring in the Gulf Monarchies, 8 GLoBaLIZATIONS 629, 631-33 (2011) (discussing the methods the governments of the Gulf countries used to combat Arab Spring unrest). See generally Lisa Anderson, Demystifying the Arab Spring, FoREIGN AFF., May/June 2011, at 2 (2011) (discussing the different experiences of the Arab Spring in Libya, Egypt, and Tunisia).

98. Frances Fox Piven, A Proud, Angry Poor, The NATIon, Jan. 2, 2012, at 33, 33. 
political nature of human rights law,"99 then this may be, at least in part, a question of reactivating the "times...[and] rhythms" of the global economy, and of the nation-state, as political questions of the first order. ${ }^{100}$ By way of doing so, international human rights law doctrine and practice offer ways of experiencing the here and now anachronistically, against the necessity of building futures or redeeming pasts, and against the "deadly eternity" of inherent dignity. ${ }^{101}$

99. Daniel Augenstein \& Hans Lindahl, Introduction: Global Human Rights Law and the Boundaries of Statehood, 23 IND. J. GLOBAL LEGAL STUD. 1 (2016).

100. Althusser, supra note 22, at 101.

101. Braun, supra note 73 , at 15 . 